\title{
Utilization of Non-Timber Forest Products Based on Traditional Culture: A Case Study of Iban Dyeing in Sarawak, Borneo, Malaysia
}

\author{
Natsuho Fujisawa ${ }^{1}$, Tohru Nakashizuka ${ }^{2}$ \\ Author Addresses: ${ }^{1}$ Graduate School of Agricultural and Life Sciences, University of Tokyo, Japan, ${ }^{2}$ Graduate School of Life \\ Sciences, Tohoku University, Aoba, Sendai, Japan \\ nacuho.f@hotmail.co.jp
}

Received: March 7, 2011

Volume 3:18-22

Published: April 6, 2012

(C)2012 Society of Ethnobiology

\section{Introduction}

In this brief report, we describe four plant species that Iban weavers use for dyes and six ingredients that they use in mordants (Supplementary Table). From September to November 2009, we interviewed four weavers and observed additional persons collecting and processing dye plants in three Iban villages whose names are Rumah Engkang, Rumah Ejon, and Rumah Nyawai. We also collected twenty-four plant vouchers which are deposited in the Sarawak Herbarium in the Forest Research Centre of Sarawak. The means by which Iban acquire dye materials varies by community and by individual weaver within each community. Generally, however, Iban collect plants when they are abundant in forests and easy to access and cultivate or, alternatively, they purchase plants that are scarce in the wild. Women use the yarns that they dye with plants to weave cloths.

\section{The Values of Iban Textiles}

In Kuching, the largest city in Sarawak, the Tun Jugah Foundation and Society Atelier Sarawak are actively involved in preserving Iban weaving traditions in various ways. For example, the Tun Jugah Foundation has a museum and a gallery to publicly exhibit the traditional textiles and folk costumes of the Iban. It also supports Iban women living near the city who engage in traditional weaving techniques. The foundation provides the Rumah Engkang people with yarns that have undergone the week-long ngar ceremony performed by a master dyer (Linggi 2001; Gavin 2004) and which residents of Rumah Engkang then weave into textiles.
The Society Atelier Sarawak highlights ngar rituals as iconic of Iban traditions and organizes ecotours for people to experience the rituals. The Society sells pua cloths that were used historically for wrapping severed heads in headhunting (Gavin 2004) and that were produced from yarns that underwent ngar rituals. The Society Atelier Sarawak works with Iban weavers by encouraging them to use new materials such as silk and to make clothes with modern materials and colors while simultaneously preserving the Iban patterns. The Society organizes fashion shows too. As the number of tourists to Malaysia has increased, the demand for Iban textiles that are colored with natural dyes has also increased. In Sarawak, due to the activities of Society Atelier Sarawak and the Tun Jugah Foundation, Iban textiles are recognized as valuable nationally as well as internationally.

\section{Acknowledgements}

We wish to express our thanks to members of the Research Institute for Humanity and Nature, Dr. G. Hasegawa of Kyoto University, members of the Tun Jugah Foundation, staff of the Forest Research Center of Sarawak, Dr. M. Domyo of the University of Shiga Prefecture, and members of the Earth Network for their helpful suggestions. We also thank Tuai Rumah (village leaders) of Rumah Ejon, Rumah Tuan, Rumah Engkang, and Rumah Nyawai, as well as other villagers for sharing their knowledge and hospitality during fieldwork, especially Tuai Rumah Ejon and his family. This work was supported by grants (to Tohru Nakashizuka) from the Research Institute for Humanity and Nature (P3-5) and the Ministry of Education, Science, Sport and Culture of Japan. 


\section{References Cited}

Gavin, Traude. 2004. Iban Ritual Textiles. Singapore

University Press, Singapore.

Linggi, Datin Amar Margaret. 2001. Ties That Bind. The

Tun Jugah Foundation, Kuching.

\section{Biosketches}

Natsuho Fujisawa, Graduate School of Agricultural and Life Sciences. The University of Tokyo, Japan.

Tohru Nakashizuka, Professor, Graduate School of Life Sciences, Tohoku University, Japan.

\section{Supplementary Table: Ethnobotanical Inventory}

Engkudu (Morinda citrifolia L. Rubiaceae)

\section{Description}

M. citrifolia is a tall evergreen tree whose root is used for dye.

\section{Distribution in the Three Villages and Plant Availability}

Rumah Engkang

M. citrifolia is cultivated in cultivated fields. Only part of the root is harvested so that the tree can be used repeatedly.

Cultivation is relatively easy and cultivators use cuttings or seeds to propagate the crop.

Rumah Ejon

This plant is not used anymore in this village. However, residents cultivate M. citrifolia to sell to residents in other villagers.

Rumah Nyawai

A large number of $M$. citrifolia trees are cultivated in fields using cuttings for propagation. Since only the root is used, the upper part of the tree is trimmed to keep them short. Some people purchase the roots from other villages.

Use

M. citrifolia $(2 \mathrm{~kg})$ and the mordant called jangau are washed, cut into pieces, mashed well and filtered through a sieve. They are mixed with the mordants $P$. betel (5 leaves), U. ovalifolia (5 leaves), and slaked lime (1/2 cup), and then boiled in water. Pretreated threads are soaked for three days, and then dried in the sun. This is repeated three or four times.

\section{Color}

Red

Engkerebai (Psychotria aurantiaca Wall. and P. viridiflora Reinw. ex Blume Rubiaceae)

\section{Description}

$P$. aurantiaca is a tree whose leaves are used for dye.

\section{Distribution in the Three Villages and Plant Availability}

Rumah Engkang

P. aurantiaca is cultivated in the same field as engkudu, although some people said that the plant was abundant enough to collect from a forest at one hour's walking distance.

Rumah Ejon

P. aurantiaca grows naturally in the gum forests or in secondary forests where the vegetation has recovered.

People collect but do not cultivate it. 


\section{Rumah Nyawai}

P. aurantiaca is mostly cultivated by weavers because its natural habitat is remote and its population is small.

Use

P. aurantiaca (2 kg), P. betel (5 leaves), and U. ovalifolia (5 leaves) are cut into pieces, mixed with slaked lime (1/2 cup), and boiled in water. Threads soaked in the hot mixture are air dried.

\section{Color}

Red

Sebangki (Coelostegia spp. Benth. Bombacaceae)

\section{Description}

Coelostegia spp. is a large tree whose bark is used for dye.

\section{Distribution in the Three Villages and Plant Availability}

Rumah Engkang

More than ten Coelostegia trees stand in a nearby forest and people collect the bark. Otherwise, weavers purchase the bark from elsewhere.

Rumah Ejon

Historically, many Coelostegia trees stood in nearby forests, but now only one tree is left near the river and the weavers ask the owner of the tree for bark. Some people ask the villagers who work as timber cutters in upstream regions to bring the plant back or buy the bark from the market in Kapit.

\section{Rumah Nyawai}

Several Coelostegia trees stand in the village. Weavers ask the owners of the trees for bark.

Use

Coelostegia spp. (1 kg), P. betel (5 leaves), and U. ovalifolia (5 leaves) are cut into pieces and boiled in water for thirty minutes. Slaked lime (1/2 cup) is added and the threads are soaked until the water cools and then dried in the sun.

\section{Color}

Red

Renggat (Marsdenia tinctoria R. Br. Apocynaceae)

\section{Description}

M. tinctoria is a perennial climber whose leaves are used for dye.

\section{Distribution in the Three Villages and Plant Availability}

M. tinctoria is cultivated together with other vegetables in all three villages (Rumah Ejon, Rumah Nyawai, Rumah Engkang). M. tinctoria grows in several months to a size sufficiently large for harvesting. Only the upper part of the plant is harvested. M. tinctoria can be easily propagated by planting cut stems.

Use

M. tinctoria (1 kg) is mixed and rubbed together with slaked lime (1/2cup), and placed in boiling water. Color develops quickly. Threads are soaked in for 2 minutes and then dried.

\section{Color}

Indigo

\section{Mordants}

Jangau (Aporosa confusa Gage and A.nitida Merr. Euphorbiaceae) 


\section{Description}

A. confusa is a tall sub-canopy tree whose bark is used for mordant.

\section{Distribution in the Three Villages and Plant Availability}

Rumah Engkang

Some people collect $A$. confusa bark from the forest where engkerebai and sbangki grow while others purchase the bark from other villagers.

Rumah Ejon

A. confusa trees grow naturally together with engkerebai in the gum forests and the bark is collected.

Rumah Nyawai

People also collect $A$. confusa bark. Although cultivation is difficult, some people cultivate by planting the seedlings collected from the forests.

Use

A. confusa is used as a mordant only for engkudu. The bark is chopped and ground before use.

\section{Effective Component}

Aluminum

Serih (Piper betel L. Piperaceae) and Sede (Uncaria ovalifolia Roxb. Rubiaceae)

\section{Description}

$P$. betel is a climbing herb related to black pepper. Its leaves are used for mordant. U. ovalifolia is also a vine whose leaves are used for mordant.

\section{Distribution in the Three Villages and Plant Availability}

These plants are cultivated in all three villages.

\section{Use}

$P$. betel is used to prepare all of the natural dyes.

\section{Effective Component}

Unknown

\section{Pretreatment}

Kepayang (Pangium edule Reinw. Flacourtiaceae)

\section{Description}

P. edule is a large tree whose seeds are used to obtain oil for the pretreatment of yarns.

\section{Distribution in the Three Villages and Plant Availability}

Rumah Engkang

$P$. edule is cultivated and oil is extracted by the villagers. Cultivation is done by planting seedlings or cuttings.

People used to eat detoxified $P$. edule nuts by boiling and soaking in water in all three regions, but they

stopped eating them because of the tedious detoxification procedure.

Rumah Ejon

P. edule is cultivated together with other trees in forests. Many families used to extract oil from the seeds after removing a poison, hydrogen cyanide, but only a few do it now for selling to other villagers.

Rumah Nyawai

Some cultivate $P$. edule to extract oil, but others buy the oil from other villages such as residents of Rumah Ejon. 
Oil

Lia (Zingiber officinale Roscoe. Zingiberaceae)

\section{Description}

Z. officinale is a kind of ground herb whose root is used for pretreatment.

Distribution in the Three Villages and Plant Availability

Rumah Engkang

Z. officinale is also cultivated in the fields but not in great enough quantities; thus, people purchase it in the market. Cultivated $Z$. officinale is also used as seasoning.

Rumah Ejon

Z. officinale is not used.

Rumah Nyawai

Z. officinale is sufficiently cultivated in the fields.

\section{Effective Component}

Unknown

Lengkuas (Z. officinale Roscoe and Alpinia galangal (L.) Willd. Zingiberaceae)

\section{Description}

A. galanga is a kind of ground herb whose root is used for the pretreatment of threads.

Distribution in the Three Villages and Plant Availability

Z. officinale plant is cultivated in the fields, and utilized for pretreatment only in Rumah Engkang. In Rumah Ejon and Rumah Nyawai nobody described Z. officinale as a material in the ngar rituals that are mentioned in the narrative above.

\section{Effective Component}

Unknown

Bangkon (Nypa fruticans Wurmb. Arecaceae)

\section{Description}

N. fruticans is a Nipa palm.

Distribution in the Three Villages and Plant Availability

Since N. fruticans does not exist in the region, people in Rumah Nyawai and Rumah Engkang purchase it or a "salty" substitute. $N$. fruticans is not used in Rumah Ejon.

\section{Effective Component}

Sodium carbonate or soda ash is obtained from the ashes of burnt and crushed N. fruticans leaves. 